\title{
Microbial transglutaminase and its application in the food industry. A review
}

\author{
Marek Kieliszek • Anna Misiewicz
}

Received: 26 March 2013 / Accepted: 14 October 2013 / Published online: 8 November 2013

(C) The Author(s) 2013. This article is published with open access at Springerlink.com

\begin{abstract}
The extremely high costs of manufacturing transglutaminase from animal origin (EC 2.3.2.13) have prompted scientists to search for new sources of this enzyme. Interdisciplinary efforts have been aimed at producing enzymes synthesised by microorganisms which may have a wider scope of use. Transglutaminase is an enzyme that catalyses the formation of isopeptide bonds between proteins. Its cross-linking property is widely used in various processes: to manufacture cheese and other dairy products, in meat processing, to produce edible films and to manufacture bakery products. Transglutaminase has considerable potential to improve the firmness, viscosity, elasticity and waterbinding capacity of food products. In 1989, microbial transglutaminase was isolated from Streptoverticillium sp. Its characterisation indicated that this isoform could be extremely useful as a biotechnological tool in the food industry. Currently, enzymatic preparations are used in almost all industrial branches because of their wide variety and low costs associated with their biotechnical production processes. This paper presents an overview of the literature addressing the characteristics and applications of transglutaminase.
\end{abstract}

\section{Introduction}

Transglutaminase (EC 2.3.2.13), i.e. protein-glutamine $\gamma$ glutamyltransferase, belongs to the class of transferases

M. Kieliszek · A. Misiewicz

Department of Microbiology, Institute of Agricultural and Food

Biotechnology, Rakowiecka, 36 St., 02-532 Warsaw, Poland

M. Kieliszek $(\triangle)$

Department of Biotechnology, Microbiology and Food Evaluation, Faculty of Food Sciences, Warsaw University of Life Sciences SGGW, Nowoursynowska 159 C St., 02-776 Warsaw, Poland e-mail: marek-kieliszek@wp.pl
(Marx et al. 2008; Trespalacios and Pla 2007). It catalyses the formation of an isopeptide bond between the group of $\gamma$ carboxamides of glutamine residues (donor) and the firstorder $\varepsilon$-amine groups of different compounds, for instance, proteins (acceptors of an acyl residue) (Fig. 1a (Buettner et al. 2012; Abd-Rabo et al. 2010; Ozer et al. 2007)).

If lysine is the acceptor of acyl, then a protein molecule is enriched with this amino acid. The transfer of acyl onto a lysine residue bound in the polypeptide chain induces the process of cross-linking, i.e. the formation of interor intramolecular cross-links $\varepsilon-(\gamma$-Glu)Lys (Fig. 1b) (Kashiwagi et al. 2002).

In addition, transglutaminase catalyses the reaction of deamination if there is an absence of free amine groups. In this case, water acts as an acyl acceptor (Fig. 1c) (Motoki and Seguro 1998; Kuraishi et al. 2001). The reactions that are catalysed by this enzyme result in significant changes in the physical and chemical properties of proteins, such as modifications in viscosity, thermal stability, elasticity and resilience of proteins.

Transglutaminases are widespread in nature (Kashiwagi et al. 2002). They are found in mammalian tissues (Yasueda et al. 1994), in many invertebrates and in microbial cells ( $\mathrm{Yu}$ et al. 2008; Griffin et al. 2002). Transglutaminase is also present in plant tissues in soy, topinambour, fodder beet and orchard apple (Falcone et al. 1993). It has been demonstrated to be involved in many physiological processes: in coagulation, in antibacterial immune reactions and in photosynthesis (Kashiwagi et al. 2002).

Transglutaminase has been isolated from Streptoverticillium sp. and Physarum polycephalum. As an extracellular enzyme, it is biosynthesised by Streptoverticillium sp. (Aidaroos et al. 2011), Streptoverticillium cinnamoneum subsp. cinnamoneum (Duran et al. 1998), Streptomyces netropsis (Yu et al. 2008), Streptoverticillium griseocarneum (Gerber et al. 1994), Streptoverticillium ladakanum (Ho et al. 2000) and 
a<smiles>[R]NC(=O)[C@H](C)[C@@H](C)[C@H](C)N</smiles>

b<smiles>C[C](C)C(N)=O</smiles>

C

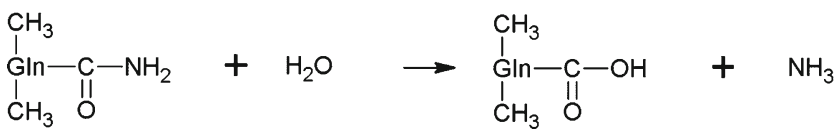

Fig. 1 The reactions catalysed by transglutaminase included. a acyltransfer reaction; b cross-linking reaction between Gln and Lys residues of proteins or peptides. c deamidation

Streptomyces lydicus (Færgemand and Qvist 1997). It has also been detected in Bacillus subtilis spores (Aidaroos et al. 2011), as shown in Table 1.

\section{Description of transglutaminase}

Microbial transglutaminase was first isolated from the Streptoverticillium sp. strain. Its active centre is composed of cysteine, histidine and either asparagine or aspartate residues. Shimba et al. (2002); Washizu et al. (1994) and Ando et al. (1989) found that transglutaminase isolated from Streptoverticillium mobaraense did not require calcium ions and showed a different reactivity to some food proteins. Such a characteristic is a very useful tool for modifying the functionality of proteins in food products (Trespalacios and Pla 2007).

The enzymatic activity of animal transglutaminase is influenced by numerous factors, among which $\mathrm{Ca}^{2+}$ ions are key (Yokoyama et al. 2004; Sharma et al. 2002). It has been demonstrated that the presence of calcium ions induces conformational changes in the enzyme molecule, which then promotes its activity and displays amino acid residues in the catalytic centre.

Transglutaminases of microbiological origin have low molecular weight, as opposed to transglutaminases isolated from animal tissues. Microbiological transglutaminase is a single polypeptide with a molecular weight of approx. $38 \mathrm{kDa}$. It is composed of 331 amino acids, with an isoelectric point at pH 8.9 (Abd-Rabo et al. 2010; Ando et al. 1989). It is a simple monomeric protein (not a glycoprotein or lipoprotein) (Yokoyama et al. 2004).

A temperature of $40^{\circ} \mathrm{C}$ at $\mathrm{pH} 5.5$ is the most favourable for the catalytic activity of transglutaminase (Ho et al. 2000), with the exception of transglutaminase isolated from Streptomyces
Table 1 Strains selected for production of microbial transglutaminase (MTGase)

\begin{tabular}{|c|c|c|}
\hline Strains & Yield (unit/mL) & References \\
\hline Actinomadura sp. T-2 & $\mathrm{n} / \mathrm{a}$ & Kim et al. (2000) \\
\hline Bacillus circulans BL32 & 0.28 & de Souza et al. (2006) \\
\hline Bacillus subtilis spores & $\mathrm{n} / \mathrm{a}$ & Aidaroos et al. (2011) \\
\hline $\begin{array}{l}\text { Corynebacterium } \\
\text { ammoniagenes }\end{array}$ & $\mathrm{n} / \mathrm{a}$ & Itaya and Kikuchi (2008) \\
\hline $\begin{array}{l}\text { Corynebacterium } \\
\text { glutamicum }\end{array}$ & $\mathrm{n} / \mathrm{a}$ & Date et al. (2004) \\
\hline Enterobacter sp. C2361 & 0.77 & Bourneow et al. (2001) \\
\hline Providencia sp. C1112 & 0.92 & Bourneow et al. (2001) \\
\hline $\begin{array}{l}\text { Streptoverticillium } \\
\text { mobaraense }\end{array}$ & $0.9-3.4$ & $\begin{array}{l}\text { Bourneow et al. (2012); } \\
\text { Zheng et al. (2002); } \\
\text { Zhu et al. (1996); } \\
\text { Gerber et al. } \\
\text { (1994); Ando et al. (1989) }\end{array}$ \\
\hline $\begin{array}{l}\text { Streptomyces platensis } \\
\quad \text { M5218 }\end{array}$ & 0.66 & Lin et al. (2006) \\
\hline $\begin{array}{l}\text { Streptomyces } \\
\quad \text { hygroscopicus }\end{array}$ & $\mathrm{n} / \mathrm{a}$ & Cui et al. (2007) \\
\hline Streptomyces lividans & $\mathrm{n} / \mathrm{a}$ & Lin et al. $(2004,2007)$ \\
\hline $\begin{array}{l}\text { Streptomyces lividans } \\
\text { JT46/pAE053 }\end{array}$ & 2.2 & Lin et al. (2006) \\
\hline Streptomyces lydicus & 1.3 & Bourneow et al. (2001) \\
\hline Streptomyces platensis & 1.4 & $\begin{array}{l}\text { Lin et al. (2006); Bourneow } \\
\text { et al. (2001) }\end{array}$ \\
\hline $\begin{array}{l}\text { Streptomyces } \\
\text { sioyansis }\end{array}$ & 3.3 & Bourneow et al. (2001) \\
\hline $\begin{array}{l}\text { Streptoverticillium } \\
\text { griseocarneum }\end{array}$ & 1.46 & $\begin{array}{l}\text { Gerber et al. (1994); Lin } \\
\text { et al. (2003) }\end{array}$ \\
\hline $\begin{array}{l}\text { Streptoverticillium } \\
\text { ladakanum } \\
\text { NRRL-3191 }\end{array}$ & $0.28-1.55$ & Téllez-Luis et al. (2004a, b) \\
\hline $\begin{array}{l}\text { Streptoverticillium sp. } \\
\quad \mathrm{s}-8112\end{array}$ & 1.46 & Kanaji et al. (1993) \\
\hline
\end{tabular}

sp., which acts most effectively at a higher temperature of $45^{\circ} \mathrm{C}$. This enzyme is not stable at $50{ }^{\circ} \mathrm{C}$ (since it loses $50 \%$ of its activity when heated for $30 \mathrm{~min}$ ) and is very susceptible to heat in the presence of ethanol. The addition of carbohydrates, such as maltodextrin, saccharose, mannose, trehalose and reduced glutathione (GSH), significantly increases the thermal stability of the enzyme (Cui et al. 2006). Casein may protect transglutaminase against degradation by extracellular proteolytic enzymes (Junqua et al. 1997). At temperatures close to $0{ }^{\circ} \mathrm{C}$, transglutaminase maintains its total enzymatic activity (Yokoyama et al. 2004).

Enzymes biosynthesised by bacteria are stable at a wide range of $\mathrm{pH}$ values, i.e. from 4.5 to 8.0. In addition, they do not require calcium ions to be activated, which is in contrast to transglutaminases of animal origin. This is a highly desirable property, from a practical point of view, for use in enzymatic preparation. The activity of transglutaminase increases in the presence of $\mathrm{Co}^{2+}, \mathrm{Ba}^{2+}$ and $\mathrm{K}^{+}$. Microbial transglutaminases 
are inhibited by $\mathrm{Zn}^{2+}, \mathrm{Cu}^{2+}, \mathrm{Hg}^{2+}$ and $\mathrm{Pb}^{2+}$ ions which bind to the thiol group of cysteine in the active centre (Macedo et al. 2010; Motoki and Seguro 1998; Ando et al. 1989).

\section{Comparison of transglutaminase from different sources}

Transglutaminases are enzymes that are commonly found inside and outside of a cell. This determines the versatility and diversity of their functions. Enzymatic activity was observed in many microorganisms and in plant and animal tissues as well. It is noteworthy that the presence of different transglutaminase forms is observed in one organism (Luciano and Arntfield 2012). Animal and plant transglutaminases manifest catalytic activity and biochemical properties similar to those of microbiological transglutaminases, despite having a lack of homology in the amino acid composition (Luciano and Arntfield 2012).

Animal transglutaminases are involved in a number of physiological processes, e.g. they participate in spermatogenesis and blood coagulation. Many forms of transglutaminases have also been identified in plants. It was also confirmed that more than one transglutaminase may function in one plant, or even in one organelle (Sobieszczuk-Nowicka et al. 2008). These enzymes play a role in plants' processes of growth and development (Samelak et al. 2010). A specific feature of a plant is transglutaminase enzyme sensitivity to light. This property applies especially to chloroplast transglutaminase (TGase), which has been confirmed by many studies (Campos et al. 2009; Sobieszczuk-Nowicka et al. 2008).

The application of isolated transglutaminase enzymes from a microbiological source has allowed for simplification of certain processes and has provided energy and economical savings. Thanks to established transgenesis procedures, gene transfer became possible and the expression of genes gave rise to transglutaminase production. The transfer of genes to expression systems such as Escherichia coli has remarkably increased production efficiency. It should also be stated that these enzymes are safe for consumers and easily biodegradable which, in contrast to chemical substances, is a great advantage.

\section{Biosynthesis of transglutaminase}

At first, most feasibility studies on transglutaminase modification were conducted using transglutaminase derived from the liver of guinea pigs (Kuraishi et al. 2001). However, the source of origin and its relatively expensive extraction and purification processes hindered the wide use of transglutaminase in the industry. The literature indicates that recently, there has been a large number of publications on the biosynthesis of transglutaminase and on its applications in the food industry. Research on this class of enzymes has been growing, and has reached a very consistent number of published reports (around 400 per year) during the last 5 years (Mehta and Eckert 2005).

The microbiological media used to culture Streptoverticillium strains are not attractive from an economical point of view due to the large amount of expensive nutrients that are required, such as yeast extract and peptone. The cost of a culture medium may constitute almost $30 \%$ of the total costs of the whole biosynthesis process (Téllez-Luis et al. 2004a). Numerous publications discuss the issues of using agricultural waste materials as a source of carbon for transglutaminase production. The composition of the media used to produce microbial transglutaminase from the Streptomyces species has been almost the same in all of the works that have been published (Ando et al. 1989). It contains yeast extract, peptone, sodium phosphate, potassium phosphate, magnesium sulphate and a carbon source (Guerra-Rodríguez and Vázquez 2013). Xylose is a hemicellulosic sugar which may be used as a potential source of carbon and energy for microbial growth. There might be more interest in xylose as a source of carbon for bacterial proliferation if the medium could be produced from inexpensive raw materials such as hemicellulosic hydrolysates, e.g. sorghum straw (Téllez-Luis et al. 2002).

The biosynthesis of transglutaminase on culture media containing hydrolysate of sorghum straw yielded an activity level of $0.34 \mathrm{U} / \mathrm{mL}$ after $72 \mathrm{~h}$ (Téllez-Luis et al. 2004a). Furthermore, the use of sugarcane molasses does not require additional procedures, such as is the case with other hydrolysates. With the use of sugarcane molasses with glycerol, up to $0.46 \mathrm{UA} / \mathrm{mL}$ was obtained (Portilla-Rivera et al. 2009). When using enzymatic hydrolysates of potato supplemented with yeast extract, corn steep liquor and casein, up to $1.12 \mathrm{U} / \mathrm{mL}$ was obtained (Guerra-Rodríguez and Vázquez 2013). The result obtained in our work, i.e. 2.95 \pm $0.3 \mathrm{U} / \mathrm{mL}$, was more than $300 \%$ of that obtained when using the above-cited agricultural wastes as the fermentation media (Guerra-Rodríguez and Vázquez 2013). The composition of sugarcane molasses and glycerol exerted a synergic effect on the biosynthesis of microbial transglutaminase by $S$. ladakanum (Téllez-Luis et al. 2004b). Téllez-Luis et al. (2004b) recorded high transglutaminase activity, i.e. $0.72 \mathrm{U} /$ $\mathrm{mL}$, when using glycerin (1,2,3-propanotriol and glycerin) as a source of carbon. Due to its high cost, however, the use of alternative sources of carbon, e.g. glycerin, generated in biodiesel production or sugarcane molasses, seems worth considering.

The biosynthesis of transglutaminase, depending on the strain, has been performed on batch cultures. The medium contained glucose, saccharose, starch or dextrins as the source of carbon (Macedo et al. 2007). A study by Ryszka et al. (2009) showed that the biosynthesis of transglutaminase to 
conduct the $S$. mobaraense strain proved to be the most suitable medium, with a pH from 6.5 to 7.0, with aminobac, corn steep liquor and yeast extract as a nitrogen source. Transglutaminase activity was obtained in the culture after $30 \mathrm{~h}$, which was $2.0 \mathrm{U} /$ $\mathrm{mL}$. The inoculation medium was composed of $2.5 \%$ of oat flakes. The use of $18 \mathrm{~h}$ of this medium in a quantity of $7.5 \%$ ( $\mathrm{vol} / \mathrm{vol}$ ) as an inoculum has been shown to be the best for obtaining high activity of transglutaminase in the production medium. However, in order to be economically interesting, industrial production requires culture media based on cheaper raw materials. Additionally, the formulation of the culture media is of critical importance because the composition affects product concentration, yield and volumetric productivity. Fermentation media can represent almost $30 \%$ of the costs of microbial production, and general media employed for the growth of Streptomyces are not economically attractive (Guerra-Rodríguez and Vázquez 2013).

Peptone, yeast extract, casein and urea are common sources of nitrogen that are used in transglutaminase biosynthesis (Gerber et al. 1994; Zhu et al. 1995). Ammonia salts have been found to be a less useful source of nitrogen (Zhu and Tramper 2008). The literature reports on the potential use of plant materials such as soy, rice, maize and wheat flour, corn steep liquor, wheat middlings or malt extract as a source of nitrogen (Zhu et al. 1995). Bourneow et al. (2012) demonstrated that peptone was the best source of nitrogen for transglutaminase extraction from the Streptomyces sp. P20 and $S$. mobaraense strains. Zhu et al. (1996) carried out studies on the optimisation of culture medium composition and found that the introduction of additional nitrogen compounds, e.g. a proper composition of amino acids, into a medium containing peptone resulted in a significant increase in transglutaminase production by $S$. mobaraense.

Amino acids play an important role in the microbiological synthesis of transglutaminase. The exact mechanism of biosynthesis has not, as yet, been fully explained, thus this stage requires further studies. The use of non-modified peptides or amino acids probably impairs transglutaminase synthesis (Zhu et al. 1995). Moreover, in a culture medium containing peptone, the highest activity of the enzyme was detected after $65 \mathrm{~h}$, as opposed to after only $40 \mathrm{~h}$ in a medium supplemented with a composition of amino acids. Junqua et al. (1997) investigated the impact of different sources of nitrogen on transglutaminase production by Streptomyces cinnamoneum and found that a culture on a medium with casein and peptone yielded three times higher activity $(0.33 \mathrm{~J} /$ $\mathrm{mL}$ ) than that in a medium supplemented with peptone only.

Investigations carried out by Aidaroos et al. (2011) revealed that ammonium sulphate and calcium chloride in a culture medium had a positive impact both on the growth of Streptomyces hygroscopicus WSH03-01 and on transglutaminase biosynthesis. The highest activity of the enzyme at $3.2 \mathrm{U} / \mathrm{mL}$ was detected after $60 \mathrm{~h}$ of culture.
The activity of transglutaminase at $1.8-3.4 \mathrm{U} / \mathrm{mL}$ was generated by $S$. mobaraense DSMZ 40847 cultured on a medium with dissolved starch and peptone (Zheng et al. 2002; Zhu et al. 1996); this culture spanned 36-60 h. Transglutaminase synthesised by the Streptomyces sp. Strain, cultured for 7 days on a medium with starch, was active at 0.05-0.2 U/mL (Iancu et al. 2009). In contrast, studies conducted by Bahrim et al. (2010) showed that Streptomyces sp. produced transglutaminase with high activity, i.e. $0.43 \mathrm{U} / \mathrm{mL}$ in a medium with peptone and glucose. In these studies, Enterobacter sp. C2361 and Providencia sp. C1112 synthesised transglutaminase with a higher activity within 24-42 h. In addition, the Providencia sp. C1112 strain had a transglutaminase activity that was comparable with $S$. mobaraense DSMZ 40847. This finding suggests that the selected isolates were a good source of transglutaminase.

In the literature, data on the impact of culture temperature and culture medium $\mathrm{pH}$ on transglutaminase production is conflicting. Gerber et al. (1994) cultured S. griseocarneum, $S$. cinnamoneum and $S$. mobaraense at $30^{\circ} \mathrm{C}$ and a stable $\mathrm{pH}$ value of 7.0. In contrast, Junqua et al. (1997) cultured $S$. cinnamoneum at $28{ }^{\circ} \mathrm{C}$ on a medium with an initial $\mathrm{pH}$ of 7.0-7.4, and they regulated the $\mathrm{pH}$ of the culture during transglutaminase biosynthesis. Zhu and Tramper (2008) cultured $S$. mobaraense at $28{ }^{\circ} \mathrm{C}$ and regulated the $\mathrm{pH}$ in order for it to remain at a level of 6.5. Data specifying the amount of cultured material and preparation procedures are presented in a few publications. The most common is a $48-\mathrm{h}$ culture material in the amount of 1 or $2 \%$ (Junqua et al. 1997). The material was cultured on media with glucose as a source of carbon and peptone as a source of nitrogen. Numerous publications have discussed transglutaminase purification, but these studies were conducted on a laboratory scale. The objective has most often been to purify the enzyme and to determine its properties as well as to produce a monoenzymatic preparation (Ho et al. 2000; Gerber et al. 1994; Klein et al. 1992).

\section{Technological process}

Processes of the purification and expression of genes encoding transglutaminase biosynthesis have been carried out with Streptomyces lividans (Washizu et al. 1994; Lin et al. 2004), E. coli (Liu et al. 2011; Yokoyama et al. 2000) and Corynebacterium glutamicum (Date et al. 2004). Currently, this enzyme is produced with the use of $S$. mobaraense. It would therefore be useful and practical to develop a more effective system of transglutaminase production that could be applied in the food industry. The literature provides little information on the commercial production process, the application of procedures and data 
on the efficiency of the whole process of transglutaminase synthesis (Fig. 2).

Recently, some studies have been carried out to produce a recombinant transglutaminase from the $E$. coli strain (Liu et al. 2011). Transglutaminase is naturally synthesised as a pro-TGase which is then processed by removal of the N-terminal pro-peptide (Marx et al. 2007). Many studies have shown that the pro-peptide is essential for overexpression of TGase in E. coli (Yu et al. 2008; Marx et al. 2007; Yokoyama et al. 2000). This is a new method of co-expression involving the direct production of active TGase. The coding sequence of transglutaminase was cloned into $E$. coli. Then, the recombinant protein was purified using nickel affinity chromatography. The specific activity of transglutaminase produced by the recombinant E. coli strain was $22 \mathrm{U} / \mathrm{mg}$ (Liu et al. 2011).

In turn, Lin et al. (2007) developed a quick and relatively simple system of purifying recombinant transglutaminase from the $S$. lividans 25-2 strain. The process of transglutaminase purification was carried out on both a laboratory and pilot scale. The enzyme was purified to a degree of 90-95\% with an activity of $61-65 \mathrm{U} / \mathrm{mg}$. The applied procedure of purification is simple and assures a high recovery. The data presented by the authors indicate that the activity of recombinant microbiological transglutaminase was 3.3 times higher than activity detected for the enzyme from Streptomyces platensis M5218 (Lin et al. 2006). The efficiency of biosynthesis with $S$. lividans 25-2 was significantly better $(78.2 \mathrm{mg} / \mathrm{L})$ than for $S$. lividans 3131-TS (Washizu et al. 1994).

In the $S$. lividans system, TGase, under the control of the tyrosinase promoter, was secreted to a level of no more than $0.1 \mathrm{mg} / \mathrm{L}$ (Washizu et al. 1994), while the level was about $5 \mathrm{mg} / \mathrm{L}$ using the $E$. coli OmpA signal peptide (Takehana et al. 1994). A level of about $250 \mathrm{mg} / \mathrm{l}$ has been achieved in $E$. coli, but the product formed an inclusion body that could be refolded in vitro (Yokoyama et al. 2000). The levels of expression in these studies were low, and it would be very difficult to produce TGase on an industrial scale via an inclusion body (Yokoyama et al. 2004). The experiments carried out by Washizu et al. (1994) and Yasueda et al. (1994) were found to be ineffective in producing large amounts of low-priced transglutaminase. However, none of the transglutaminase production processes were commercialised.

Investigations conducted by Itaya and Kikuchi (2008) demonstrated that Corynebacterium ammoniagenes was capable of biosynthesising considerable amounts of transglutaminase in comparison with the $C$. glutamicum that was commonly used in the biosynthesis of this enzyme (Yokoyama et al. 2004). These strains are widely applied for the industrial production of amino acids, such as lysine and glutamate.

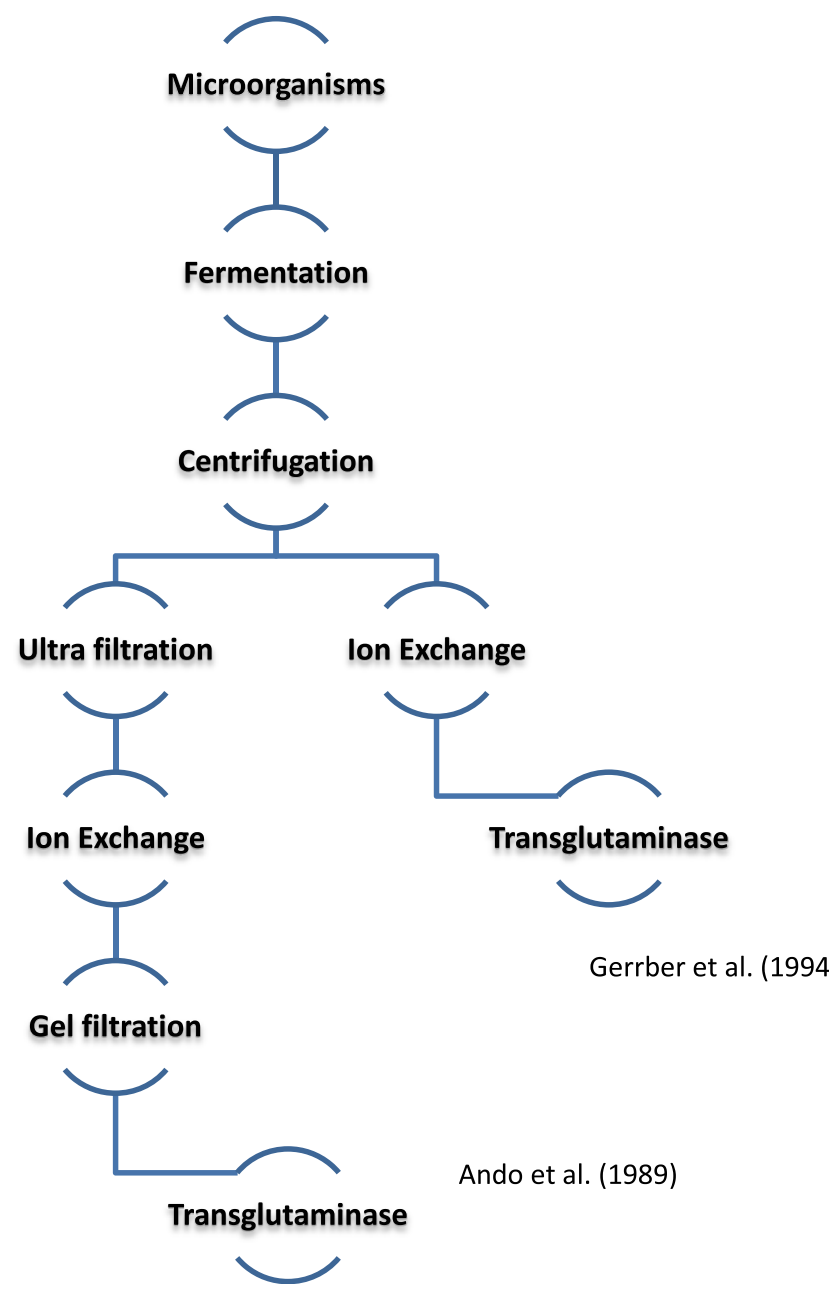

Fig. 2 Process chart of transglutaminase production

Transglutaminase is widely used in different branches of the industry because of its ability to modify the physical and chemical properties of proteins. To date, a bacterial expression system with Streptoverticillium mobaraensis has mainly been used to biosynthesise transglutaminases. This system, however, has some drawbacks, involving, e.g. problems related to post-translational protein modification (Griffin et al. 2002). Research should thus be pursued to develop a cheaper and more efficient system that will allow for a reduction of costs associated with the distribution, storage, extraction and purification of recombinant proteins.

\section{Transglutaminase preparations}

Transglutaminase preparations can be the solution to many technological problems related to appropriate efficiency and food texture associated with the ability of utilising raw material of less technological usefulness, e.g. mechanically deboned meat, collagen and blood proteins. It is generally known that the use of phosphates on a large scale in meat 
processing technology has been addressed through health concerns. In the available literature, it is possible to find information on restricting phosphate applicability in meat processing technology (Pyrcz et al. 2012; Flores et al. 2007).

There are different microbiologically derived enzymatic preparations on the market which contain transglutaminase obtained in a biosynthesis-dependent manner via Streptoverticillium mobaraense. An example can be Activa ${ }^{\circledR}$ EB and Activa ${ }^{\circledR}$ WM (Ajinomoto, Japan). These enzymes neutralise changes in the texture caused by freezing of the raw material: chicken meat, chicken batters (Arciszewska et al. 2004). Other raw materials containing transglutaminase, e.g. SAPRONA TG1 and SAPRONA TG2 Prima Vera Poland Sp. $\mathrm{z}$ o.o. (Poland), are utilised in salami production. They allow faster maturation and a clear profile of the product. They improve the structure of meat and minimise loss during thermal processing and rationing. SAPRONA TG 1 has been designed for a system where the quantity of the protein is efficient for a cross-linking reaction (http://www.pvpolska.pl/). Enzyme preparation from PMT TRADING sp. $z$ o.o. (Poland) is used as a processing aid in the production of fermented dairy products. Preparation increases the ability of utilising heatshocked whey proteins through inclusion in the sow net and improving the sensory characteristics of the ready-made product. Better cream consistency and condensation of dry cottage cheese have been observed (http://www.saprovia.com/).

Using transglutaminase in the food industry, independently from the source of origin, constitutes a natural technological method. Enzymatic modification of food constituents has a greater chance of being accepted by the food industry than the commonly used chemical methods.

\section{Applications of transglutaminase}

Preparations containing transglutaminase have a potentially wide range of applications (Fig. 3 and Table 2). They commonly attract interest because they are used in the food industry for the cross-linking of proteins (Buettner et al. 2012; Giosafatto et al. 2012; Kashiwagi et al. 2002; Zheng et al. 2002). Transglutaminase is also used to produce, for instance, protein or composite edible films (Porta et al. 2011a, b).

Transglutaminase is an enzyme that catalyses the formation of cross-links both within a protein molecule and between molecules of different proteins (Mahmood and Sebo 2009). This feature has an impact on the changes in protein functionalities: solubility, emulsifying capacity, foaming properties and gelation (Giosafatto et al. 2012). Studies carried out by Monogioudi et al. (2011) demonstrated that the enzymatic cross-linking of $\beta$-casein was more resistant to digestion by pepsin than was the case with non-cross-linked $\beta$-casein. The authors concluded that these results might exert a considerable impact on the development of new types of

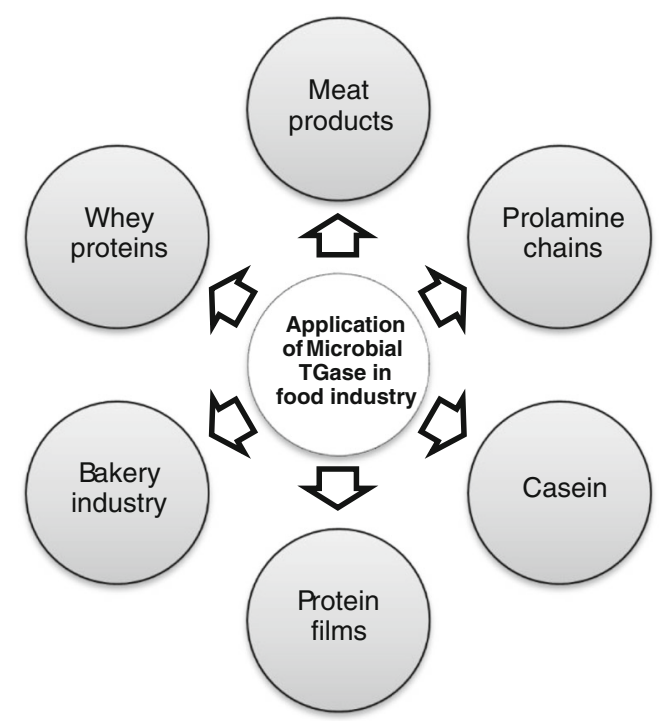

Fig. 3 Possible applications of microbial transglutaminase

foods with better structural characteristics (Giosafatto et al. 2012). Polymerisation of milk proteins with transglutaminase results in the formation of a protein film which improves the functional properties of dairy products (Rossa et al. 2011). According to Hiller and Lorenzen (2009), cross-linking is a predominant process that leads to the formation of specific

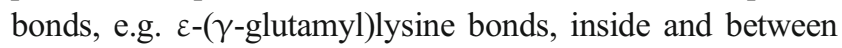
the isopeptide chains.

In the baking industry, transglutaminase is used to improve the quality of flour, the texture and volume of bread (Moore et al. 2006) and the texture of pasta after cooking (Kuraishi et al. 1997). From a nutritional point of view, rice flour

Table 2 Application of MTGase on food processing

\begin{tabular}{|c|c|c|c|}
\hline Source & Product & Effect & Reference \\
\hline Meat & $\begin{array}{l}\text { Restructured } \\
\text { meat }\end{array}$ & $\begin{array}{l}\text { Restructured meat } \\
\text { texture and } \\
\text { appearance, } \\
\text { increased } \\
\text { hardness }\end{array}$ & $\begin{array}{l}\text { Kuraishi et al. (1997); } \\
\text { Motoki and Seguro } \\
\text { (1998); Trespalacios } \\
\text { and Pla (2007) }\end{array}$ \\
\hline Fish & $\begin{array}{l}\text { Fish paste, } \\
\text { restructured } \\
\text { product }\end{array}$ & Increased hardness & Téllez-Luis et al. (2002) \\
\hline Milk & $\begin{array}{l}\text { Cream, } \\
\text { deserts, } \\
\text { milk } \\
\text { drinks, } \\
\text { dressings }\end{array}$ & $\begin{array}{l}\text { Improved quality } \\
\text { and texture }\end{array}$ & $\begin{array}{l}\text { Lauber et al. (2000); } \\
\text { Şanlı et al. (2011) }\end{array}$ \\
\hline Casein & $\begin{array}{l}\text { Cross linked } \\
\text { protein }\end{array}$ & $\begin{array}{l}\text { Allergenicity } \mathrm{r} \\
\text { eduction }\end{array}$ & $\begin{array}{l}\text { Lauber et al. (2000); } \\
\text { Ozer et al. (2007) }\end{array}$ \\
\hline Wheat & Baked foods & $\begin{array}{l}\text { Improved texture } \\
\text { and high volume }\end{array}$ & Gerrard et al. (2001) \\
\hline Gelatin & Sweet foods & $\begin{array}{l}\text { Low calorie foods } \\
\text { with good texture } \\
\text { and elasticity }\end{array}$ & Giosafatto et al. (2012) \\
\hline
\end{tabular}


contains many valuable nutrients, for instance protein, fibre and vitamins $\mathrm{E}$ and $\mathrm{B}$; however, its use is limited to nonfermented bakery products. Research conducted by Gujral and Rosell (2004) has demonstrated that the addition of transglutaminase to rice flour improved the rheological properties of dough by increasing the triglyceride content.

Transglutaminase is also widely used in the meat industry, mainly in the manufacture of restructured meat (Kuraishi et al. 1997). Apart from having a positive impact on the texture of the final product, the use of transglutaminase preparations facilitates strong cohesion of a meat block without the need for thermal processing or the addition of salt or phosphates. The use of transglutaminase in meat processing significantly improves the texture of the final product, which results in, for example, an increase in its hardness. Moreover, it strengthens the texture of homogenised sausages made of pork, beef or poultry meat. The addition of transglutaminase allows for the utilisation of lower quality raw materials, such as collagen, blood proteins and mechanically deboned meat, in manufacturing meat products with a higher nutritive value by supplementing it with amino acids in which it is deficient (e.g. exogenous lysine). The application of transglutaminase has created new technological opportunities for producing fine and coarse-minced sausages, Vienna sausages and smoked meat. Instead of high-quality meat, lower quality raw materials and additives, such as skimmed milk powder, soy or wheat flour, can now be used to manufacture these products. The impact of the enzyme on the proteins of these raw materials yields products which do not differ in appearance, texture, odour, taste and nutritional value from analogical products made exclusively of high quality meat (Motoki and Seguro 1998). The use of transglutaminase allows for the production of some types of processed meats with a lower fat content; in this case, sodium casein treated with transglutaminase replaces previously extracted animal fat. Products with fillers do not differ in their organoleptic properties from conventionally processed meat (Nielsen 1995).

In the dairy industry, transglutaminase has been introduced into the production of numerous products, e.g. yoghurts, in order to prevent syneresis or to make their texture firmer and softer (Lorenzen et al. 2002). Transglutaminase-modified casein makes it possible to manufacture dairy products with better structure and consistency. This method is used to produce yoghurts from milk incubated with transglutaminase (Ozer et al. 2007) - they have a homogenous, firm and creamy consistency as well as a smooth and dry curd surface. This results from a reduction in syneresis (Lorenzen et al. 2002). Such yoghurts serve as a base to produce creams, frozen desserts, ice cream, milk drinks and dressings (Nielsen 1995; Lauber et al. 2000; Sanlı et al. 2011).

Transglutaminase is used in the manufacturing of cheese, and curd yield is increased by using transglutaminase in the manufacturing process. Three patterns for producing natural cheese with transglutaminase are proposed: (1) adding transglutaminase to milk, heating the milk for pasteurisation and deactivation of the enzyme, and then adding rennet to the milk; (2) adding rennet to the milk and then adding transglutaminase; (3) adding transglutaminase to the milk at the same time as rennet (Kuraishi et al. 2001). Investigations carried out by Mahmood and Sebo (2009) and Cozzolino et al. (2003) on improving the yield and properties of cheese demonstrated that the addition of transglutaminase before the addition of rennet prevented milk coagulation; whereas simultaneous addition of the enzyme and rennet significantly reduced the resistance and hardness of the cheese, the protein level and the fat content in whey.

Transglutaminases are currently being used in baking technologies to form links between polypeptide prolamin chains. The first data on the baking of pastry with the addition of transglutaminase were provided by Gottmann and Sprossler (1992). Transglutaminase was found to have a positive impact on the stability and volume of dough as well as on the improvement of the baking quality of poor flour and, consequently, the texture of the bread (Marco and Rosell 2008). Losche (1995) reported that transglutaminase improved the rheological properties of dough and ensured proper pore size and bread elasticity after baking. In addition, transglutaminases were shown to improve water adsorption by dough (Kuraishi et al. 2001). Modification of wheat flour proteins with transglutaminase increases the elasticity and resilience of dough as well as the volume of bread by $14 \%$ in comparison with pastry made from traditionally prepared dough (Gerrard et al. 2001).

Transglutaminase allows for the development of entirely new products, e.g. protein films used to coat fresh vegetables and fruits and processed food products to extend their shelf life and freshness (Di Pierro et al. 2011). Whey protein modified with transglutaminase is used to produce such films. These films are edible and may be consumed together with food products (Marquez et al. 2013). Moreover, depending on the technology, they have different water permeability, elasticity, resilience, resistance to tension and mechanical damage (Mahmoud and Savello 1993; Yildirim and Hettiarachchy 1998). Increasingly frequently, transglutaminase is being utilised in many branches of the industry as a protein modifier. There is optimism about the potential use of transglutaminase to improve the nutritional values of deficient proteins by inserting the desired amino acids and peptides. It has been suggested that this enzyme could be used to block allergenic and proteolysis-resistant peptides in soy proteins (Babiker et al. 1998). Numerous products of protein modification with transglutaminase are being utilised in the leather, cosmetics and pharmaceutical industries (Zhu et al. 1995; Nielsen 1995). 
Transglutaminases may, in the future, be used to reconstruct bonds between polypeptide prolamin chains. The formation of isobonds with the support of glutamine probably inhibits the process of the recognition of this peptide fragment by $\mathrm{T}$ cells, and therefore it blocks the mechanism that leads to the development of celiac disease (Molberg et al. 1998).

\section{Summary}

Transglutaminase, because of its unique properties, is an enzyme that is widely used in many branches of the food industry. It has been recognised as safe (GRAS) by an independent panel of scientific experts. The discovery that it has an inexpensive source of its biosynthesis, i.e. by microorganisms, has afforded an opportunity for a wider and more practical application of this enzyme. Further research and development towards cost-efficient production of transglutaminase by microorganisms may result in the development of more accessible products with a wider scope of use. A mechanistic approach aims at identifying novel and promising areas of transglutaminase utilisation which will lead to its safe use in the food industry. The great applicability of microbial transglutaminases has prompted a search for new strains that would be capable of synthesising substantial amounts of the enzymes with high activity from the cheapest substrates possible.

Open Access This article is distributed under the terms of the Creative Commons Attribution License which permits any use, distribution, and reproduction in any medium, provided the original author(s) and the source are credited.

\section{References}

Abd-Rabo FHR, EI-Dieb SM, Abd-EI-Fattah AM, Sakr SS (2010) Natural state changes of cows' and buffaloes' milk proteins induced by microbial transglutaminase. J Am Sci 6:612-620

Aidaroos HI, Du G, Chen J (2011) Microbial fed-batch production of transglutaminase using ammonium sulphate and calcium chloride by Streptomyces hygroscopicus. Biotechnol Bioinf Bioeng 1(2): 173-178

Ando H, Adachi M, Umeda K, Matsuura A, Nonaka M, Uchio R, Tanaka H, Motoki M (1989) Purification and characteristics of a novel transglutaminase derived from microorganisms. Agric Biol Chem 53:2613-2617

Arciszewska A, Cegiełka A, Mroczek J (2004) Effect of transglutaminase and sodium chloride addition on properties of batters of chilled and frozen chicken meat. Acta Sci Pol Technol Aliment 3:19-25

Babiker EFE, Matsudomi N, Kato A (1998) Masking of antigen structure of soybean protein by conjugation with polysaccharide and crosslinkage with microbial transglutaminase. Nahrung 42:158-159

Bahrim G, Iancu C, Buțu N, Negoiță TG (2010) Production of a novel microbial transglutaminase using Streptomyces sp. polar strains. Rom Biotech Lett 15:5197-5203
Bourneow C, Benjakul S, H-Kittikun A (2012) Hydroxamate-based colorimetric method for direct screening of transglutaminaseproducing bacteria. World J Microb Biot 28:2273-2277

Bourneow C, Benjakul S, Sumpavapol P, H-Kittikun A (2001) Isolation and cultivation of transglutaminase producing bacteria from seafood processing factories. Innovat Rom Food Biotechnol 10:28-39

Buettner K, Hertel TC, Pietzsch M (2012) Increased thermostability of microbial transglutaminase by combination of several hot spots evolved by random and saturation mutagenesis. Amino Acids 42: 987-996

Campos A, Carvajal-Vallejos PK, Villalobos E, Franco CF, Almeida AM, Coelho AV, Torné JM, Santos M (2009) Characterisation of Zea mays L. plastidial transglutaminase: interactions with thylakoid membrane proteins. Plant Biol 12(5):708-716

Cozzolino A, Di Pierro P, Mariniello L, Sorrentino A, Masi P, Porta R (2003) Incorporation of whey proteins into cheese curd by using transglutaminase. Biotechnol Appl Biochem 38:289-195

Cui L, Du G, Zhang D, Liu H, Chen J (2007) Purification and characterization of transglutaminase from a newly isolated Streptomyces hygroscopicus. Food Chem 105:612-618

Cui L, Zhang D-X, Huang L, Liu H, Du G-C, Chen J (2006) Stabilization of a new microbial transglutaminase from Streptomyces hygroscopicus WSH03-13 by spray drying. Process Biochem 41:1427-1431

Date M, Yokoyama K, Umezawa Y, Matsui H, Kikuchi Y (2004) High level expression of Streptomyces mobaraensis transglutaminase in Corynebacterium glutamicum using a chimeric pro-region from Streptomyces cinnamoneus transglutaminase. J Biotechnol 110:219 226

Di Pierro P, Sorrentino A, Mariniello L, Giosafatto CVL, Porta R (2011) Chitosan/whey protein film as active coating to extend Ricotta cheese shelf-life. LWT-Food. Sci Technol 44:2324-2327

Duran R, Junqua M, Schmitter JM, Gancet C, Goulas P (1998) Purification, characterisation, and gene cloning of transglutaminase from Streptoverticillium cinnamoneum CBS 683.68. Biochimie 80:313-319

Færgemand M, Qvist KB (1997) Transglutaminase: effect on rheological properties, microstructure and permeability of set style acid skim milk gel. Food Hydrocoll 11:287-292

Falcone P, Serafin-Fracassini D, Del-Duca S (1993) Comparative studies of transglutaminase activity and substrates in different organs of Helianthus tuberosus. J Plant Physiol 142:263-273

Flores NC, Boyle EAE, Kastner CL (2007) Instrumental and consumer evaluation of pork restructured with activa ${ }^{\mathrm{TM}}$ or with Fibrimex ${ }^{\mathrm{TM}}$ formulated with and without phosphate. Food Sci Technol 40:179-185

Gerber U, Jucknischke U, Putzien S, Fuchsbauer HL (1994) A rapid and simple method for the purification of transglutaminase from Streptoverticillium mobaraense. Biochem J 299:825-829

Gerrard JA, Fayle SE, Brown PA, Sutton KH, Simmons L, Rasiah I (2001) Effects of microbial transglutaminase on the wheat proteins of bread and croissant dough. J Food Sci 66:782-786

Giosafatto CVL, Rigby NM, Wellner N, Ridout M, Husband F, Mackie AR (2012) Microbial transglutaminase-mediated modification of ovalbumin. Food Hydrocoll 26:261-267

Gottmann K, Sprossler B (1992) Backmittel oder Backmehl, sowie Verfahren zur Herstellung von Backteigen und Backwaren. Europe Patent $0,492,406$

Griffin M, Casadio R, Bergamini CM (2002) Transglutaminases: nature's biological glues. Biochem J 368:377-396

Guerra-Rodríguez E, Vázquez M (2013) Evaluation of a novel low-cost culture medium containing exclusively milk, potato and glycerol for microbial transglutaminase production by Streptomyces mobaraensis. Chem Eng Res Des. doi:10.1016/j.cherd.2013.06.027

Gujral SH, Rosell MC (2004) Functionality of rice flour modified with a microbial transglutaminase. J Cereal Sci 39:225-230

Hiller B, Lorenzen PC (2009) Functional properties of milk proteins as affected by enzymatic oligomerisation. Food Res Int 42(8): 899-908 
Ho ML, Leu SZ, Hsieh JF, Jiang ST (2000) Technical approach to simplify the purification method and characterization of microbial transglutaminase produced form Streptoverticillium ladakanum. J Food Sci 65:76-80

Iancu C, Butu N, Bahrim G (2009) Preliminary studies regarding transglutaminase synthesis by polar filamentous bacteria of the genus Streptomyces sp. Innov Rom Food Biotechnol 4:12-15

Itaya H, Kikuchi Y (2008) Secretion of Streptomyces mobaraensis protransglutaminase by coryneform bacteria. Appl Microbiol Biotechno 78:621-625

Junqua M, Duran R, Gancet C, Goulas P (1997) Optimization of microbial transglutaminase production using experimental designs. Appl Microbiol Biotechno 48:730-734

Kanaji T, Ozaki H, Takano T, Ide H, Motoki M, Shimonishi Y (1993) Primary structure of microbial transglutaminases from Streptoverticillium sp. Strain s-8112. J Biol Chem 268:11565-11572

Kashiwagi T, Yokoyama K, Ishikawa K, Ono K, Ejima D, Matsui H, Suzuki E (2002) Crystal structure of microbial transglutaminase from Streptoverticillium mobaraense. J Biol Chem 277:4425244260

Kim HS, Jung S-H, Lee I-S, Yu T-S (2000) Production and characterization of a novel microbial transglutaminase from Actinomadura sp. T-2. J Microbiol Biotechnol 10:187-194

Klein JD, Guzman E, Kuehen GD (1992) Purification and partial characterization of transglutaminase from Physarum polycephalum. J Bacteriol 174:2599-2605

Kuraishi C, Sakamoto J, Yamazaki K, Susa Y, Kuhara C, Soeda T (1997) Production of restructured meat using microbial transglutaminase without salt or cooking. J Food Sci 62:488-490

Kuraishi C, Yamazaki K, Susa Y (2001) Transglutaminase: its utilization in the food industry. Food Rev Int 17:221-246

Lauber S, Henle T, Klostermeyer H (2000) Relationship between the crosslinking of caseins by transglutaminase and the gel strength of yoghurt. Eur Food Res Technol 210:305-309

Lin S-J, Hsieh Y-F, Wang P-M, Chu W-S (2007) Efficient purification of transglutaminase from recombinant Streptomyces platensis at various scales. Biotechnol Lett 29:111-115

Lin Y-S, Chao M-L, Liu CH-H, Chu W-S (2004) Cloning and expression of the transglutaminase gene from Streptoverticillium ladakanum in Streptomyces lividans. Process Biochem 39:591-598

Lin Y-S, Liu C-H, Chu W-S (to Food Industry Research and Development, Taiwan) (2003) Transglutaminase gene of Streptomyces ladakanum and the transglutaminase encoded therefrom. US Patent 6,660,510

Lin Y-S, Chao M-L, Liu C-H, Tseng M, Chu W-S (2006) Cloning of the gene coding for transglutaminase from Streptomyces platensis and its expression in Streptomyces lividans. Process Biochem 41:519524

Liu S, Zhang D, Wang M, Cui W, Chen K, Du G, Chen J, Zhou Z (2011) The order of expression is a key factor in the production of active transglutaminase in Escherichia coli by co-expression with its propeptide. Microb Cell Fact 23;10:112

Lorenzen PC, Neve H, Mautner A, Schlimme E (2002) Effect of enzymatic cross-linking of milk proteins on functional properties of set-style yoghurt. Int J Dairy Technol 55:152-157

Losche IK (1995) Enzymes in baking. The World of Ingredients MayJune 22-25

Luciano FB, Arntfield SD (2012) Use of transglutaminases in foods and potential utilization of plants as a transglutaminase source - review. Biotemas 25(4):1-11

Macedo JA, Cavallieri ALF, da Cunha RL, Sato HH (2010) The effect of transglutaminase from Streptomyces sp. CBMAI 837 on the gelation of acidified sodium caseinate. Int Dairy J 20:673-679

Macedo JA, Sette LD, Sato HH (2007) Optimization of medium composition for transglutaminase production by a Brazilian soil Streptomyces sp. Electr J Biotechnol 10:618-626
Mahmood WA, Sebo NH (2009) Effect of microbial transglutaminase treatment on soft cheese properties. Mesopotamia J of Agric 37, http://www.iasj.net/iasj?func $=$ fulltext\&aId $=27525$

Mahmoud R, Savello PA (1993) Solubility and hydrolyzability of films produced by transglutaminase catalytic cross-linking of whey protein. J Dairy Sci 76:29-35

Marco C, Rosell CM (2008) Breadmaking performance of protein enriched, gluten-free breads. Eur Food Res Technol 227:1205-1213

Marquez GR, Di Pierro P, Esposito M, Mariniello L, Porta R (2013) Application of transglutaminase-crosslinked Whey Protein/Pectin Films as water barrier coatings in fried and baked foods. Food Bioprocess Technol. doi:10.1007/s11947-012-1045-9

Marx CK, Hertel TC, Pietzsch M (2007) Soluble expression of a protransglutaminase from Streptomyces mobaraensis in Escherichia coli. Enzyme Microb Technol 40:1543-1550

Marx CK, Hertel TC, Pietzsch M (2008) Random mutagenesis of a recombinant microbial transglutaminase for the generation of thermostable and heat sensitive variants. J Biotechnol 136:156-162

Mehta K, Eckert R (2005) Transglutaminases - family of enzymes with diverse functions. Karger, Basel, Switzerland

Molberg O, Mcadam SN, Körner R, Quarsten H, Kristiansen Ch, Madsen L, Fugger L, Scott H, Norén O, Roepstorff P, Lundin KEA, Sjöström H, Sollid LM (1998) Tissue transglutaminase selectively modifies gliadin peptides that are recognized by gut-derived $\mathrm{T}$ cells in celiac disease. Nat Med 4(6):713-717

Monogioudi E, Faccio G, Lille M, Poutanen K, Buchert J, Mattinen M-L (2011) Effect of enzymatic cross-linking of $\beta$-casein on proteolysis by pepsin. Food Hydrocoll 25:71-81

Moore MM, Heinbockel M, Dockery P, Ulmer MH, Arendt EK (2006) Network formation in gluten-free bread with application of transglutaminase. Cereal Chem 83:28-36

Motoki M, Seguro K (1998) Transglutaminase and its use for food processing. Trends Food Sci Tech 9:204-210

Nielsen PM (1995) Reactions and potential industrial applications of transglutaminase. Review of literature and patents. Food Biotech 6:119-156

Ozer B, Kirmaci HA, Oztekin S, Hayaloglu A, Atamer M (2007) Incorporation of microbial transglutaminase into non-fat yogurt production. Int Dairy J 17:199-207

Porta R, Di Pierro P, Sorrentino A, Mariniello L (2011a) Promising perspectives for transglutaminase in "bioplastics" production. Biotechnol Biomaterial 1:102e. doi:10.4172/2155-952X.1000102e

Porta R, Mariniello L, Di Pierro P, Sorrentino A, Giosafatto CV (2011b) Transglutaminase crosslinked pectin- and chitosan-based edible films: a review. Crit Rev Food Sci Nutr 51:223-38

Portilla-Rivera OM, Tellez-Luis SJ, Ramirez de Leon JA, Vazquez M (2009) Production of microbial transglutaminase on media made from sugar cane molasses and glycerol. Food Technol Biotechnol 47:19-26

Pyrcz J, Kowalski R, Danyluk B, Bilska A (2012) Technologiczna przydatność preparatów transglutaminazy w produkcji szynki parzonej. Nauka Przyr Technol 6(4):81

Rossa PN, De Sa EMF, Burin VM, Bordignon-Lui MT (2011) Optimization of microbial transglutaminase activity in ice cream using response surface methodology. Lwt-Food Sci Technol 44: $29-34$

Ryszka L, Krakowiak A, Trzcińska M, Czakaj J (2009) Effect of culture conditions on biosynthesis of transglutaminase by Streptoverticillium mobaraense. Pamiętnik Puławski 15:619630

Samelak A, Sobieszczuk-Nowicka E, Legocka J (2010) Transglutaminazy i ich biologiczne funkcje. Postepy Biol Komorki 37(3):599-612

Şanli T, Lezgin E, Deveci O, Şenel E, Benli M (2011) Effect of using transglutaminase on physical, chemical and sensory properties of set-type yoghurt. Food Hydrocoll 25:1477-1481 
Sharma R, Zakora M, Qvist KB (2002) Susceptibility of an industrial $\alpha$ lactalbumin concentrate to cross-linking by microbial transglutaminase. Int. Dairy J 12:1005-1012

Shimba N, Yokoyama Y, Suzuki E (2002) NMR-based screening method for transglutaminases: rapid analysis of their substrate specificities and reaction rates. J Agric Food Chem 50:1330-1334

Sobieszczuk-Nowicka E, Krzesłowska M, Legocka J (2008) Transglutaminases and their substrates in kinetin-stimulated etioplast-to-chloroplast transformation in cucumber cotyledons. Protoplasma 233(3-4):187-194

Souza CFV, Flôres SH, Ayub MAZ (2006) Optimization of medium composition for the production of transglutaminase by Bacillus circulans BL32 using statistical experimental methods. Process Biochem 41:1186-1192

Takehana S, Washizu K, Ando K, Koikeda S, Takeuchi K, Matsui H, Motoki M, Takagi H (1994) Chemical synthesis of the gene for microbial transglutaminase from Streptoverticillium and its expression in Escherichia coli. Biosci Biotechnol Biochem 58:88 92

Téllez-Luis SJ, González-Cabriales JJ, Ramírez JA, Vázquez M (2004a) Production of transglutaminase by Streptoverticillium ladakanum NRRL-3191 grown on media made from hydrolysates of sorghum straw. Food Technol Biotechnol 42:1-4

Téllez-Luis SJ, Ramírez JA, Vázquez M (2004b) Production of transglutaminase by Streptoverticillium ladakanum NRRL-3191 using glycerol as carbon source. Food Technol Biotechnol 42:75-81

Téllez-Luis SJ, Uresti RM, Ramírez JA, Vázquez M (2002) Low-salt restructured fish products using microbial transglutaminase. J Sci Food Agr 82:953-959

Trespalacios P, Pla R (2007) Simultaneous application of transglutaminase and high pressure to improve functional properties of chicken meat gels. Food Chem 100:264-272

Washizu K, Ando K, Koikeda S, Hirose S, Matsuura A, Takagi H, Motoki M, Takeuchi K (1994) Molecular cloning of the gene for microbial transglutaminase from Streptoverticillium and its expression in Streptomyces lividans. Biosci Biotechnol Biochem 58:82-87

Yasueda H, Kumazawa Y, Motoki M (1994) Purification and characterization of a tissue-type transglutaminase from red sea bream (Pagrus major) Biosci. Biotech Biochem 1994:20412045

Yildirim M, Hettiarachchy NS (1998) Properties of films produced by crosslinking whey proteins and $11 \mathrm{~S}$ globulin using transglutaminase. J Food Sci 63:248-252

Yokoyama K, Nakamura N, Seguro K, Kubota K (2000) Overproduction of microbial transglutaminase in Escherichia coli, in vitro refolding, and characterization of the refolded form. Biosci Biotechnol Biochem 64:1263-1270

Yokoyama K, Nio N, Kikuchi Y (2004) Properties and applications of microbial transglutaminase. Appl Microbiol Biotechnol 64:447-454

Yu YJ, Wu SC, Chan HH, Chen YC, Chen ZY, Yang MT (2008) Overproduction of soluble recombinant transglutaminase from Streptomyces netropsis in Escherichia coli. Appl Microbiol Biotechnol 81:523-532

Zheng MY, Du GC, Chen J, Lun SY (2002) Modelling of temperature effects on batch microbial transglutaminase fermentation with Streptoverticillium mobaraense. World J Microb Biot 18:767-771

Zhu Y, Rizeman A, Tramper J, Bol J (1995) Microbial transglutaminase - a review of its production and application in food processing. Appl Microbiol Biotechnol 44:277-282

Zhu Y, Rizeman A, Tramper J, Bol J (1996) Medium design based on stoichiometric analysis of microbial transglutaminase production by Streptoverticillium mobaraense. Biotech Bioeng 50:291-298

Zhu Y, Tramper J (2008) Novel applications for microbial transglutaminase beyond food processing. Trends Biotechnol 26: $559-565$ 